\title{
Tantangan Industri Kreatif-Game Online di Indonesia
}

\author{
Choirul Fajri \\ Jurusan Ilmu Komunikasi, Universitas Ahmad Dahlan
}

\begin{abstract}
Abstrak
Perkembangan teknologi informasi dan komunikasi berlangsung begitu cepat. Tidak hanya untuk memenuhi kebutuhan informasi saja, namun juga memenuhi kebutuhan hiburan. Perkembangan ini mendorong bangkitnya industri kreatif berbasis teknologi komunikasi dan informasi, salah satunya adalah game online.industri ini ternyata mampu memberikan kontribusi pertumbuhan ekonomi. Namun demikian industri ini masih menghadapi berbagai kendala seperti keterbatasan pengetahuan, modal, serta infrastruktur. Dampaknya adalah munculnya game online yang menjual pornografi dan kekerasan untuk mempercepat penjuaan. Untuk itu perlu kerjasama antara pengembang game online dengan pemerintah agar industri iniberjalan dengan sehat. Pengembang game online juga harus lebih memperhatikan kualitas game yang diproduksinya.
\end{abstract}

\section{Kata kunci: Industri kreatif, game online, teknologi komunikasi dan informasi}

\section{Abstract}

Information and communication technology currently has grown to such an extent, not only to meet the needs for information only, but now has grown to the fulfillment of the will of entertainment. These developments, and then bring up the creative industries technology-based communication and information, one of them is online gaming. Creative industries in this area, has become a phenomenon by itself, and makes it as one of the important sectors for economic growth. However, based on the data we get, there are still constraints faced in the development of this industry, such as: the limitations of knowledge, capital, the absence of Government support, as well as the lack of adequate infrastructure. The negative impact was unavoidable as well as from the industry, for example, will the existence of addiction for the gamers who have an impact on crime and action elements of pornography are also inherent in this online game. Therefore, it takes the good cooperation between the developers of the game and also the Government to be able to develop the online gaming industry. There is awareness of the game developer to make a quality game play and has educational values.

Keywords: creative industry, Online games, communication and Information Technology.

\section{Pendahuluan}

Seiring dengan perkembangan teknologi komunikasi dan informasi, saat ini perangkat teknologi tidak hanya dituntut untuk memiliki satu fungsi semata namun beberapa fungsi sekaligus untuk memenuhi kebutuhan manusia. Tuntutan terhadap satu perangkat dengan banyak fungsi tersebut mendorong adanya kreativitas dari manusia itu sendiri untuk kemudian mengembangkan fungsi tersebut. Salah satu terobosan besar sebagai upaya untuk mengembangkan fungsi dari teknologi adalah kemunculkan internet. Internet saat ini tidak hanya digunakan untuk memenuhi kebutuhan informasi namun juga pada hal-hal yang bersifat hiburan (entertainment). Salah satu hal yang cukup banyak mendapat perhatian dari 
masyarakat berkaitan dengan hiburan internet adalah game.

Perkembangan game yang dahulu hanya dapat dimainkan secara offline, dengan adanya game internet dapat dimainkan secara online dengan tidak ada lagi keterbatasan waktu. Game online saat ini telah berkembang sedemikian rupa seiring dengan perkembangan dan kemajuan teknologi itu sendiri (Afrianto dalam Febriana, 2012:1).

Perkembangan game online di Indonesia dimulai pada pertengahan tahun 1990-an saat game Nexian beredar. Saat itu, salah satu game online yang sangat digemari oleh masyarakat luas adalah Ragnarok. Pesatnya perkembangan game online tersebut memunculkan berbagai jenis game online lainnya seperti Dota Online, Atlantica Online, Counter Strike, Point Blank, serta Three Kingdom Online. Jika ditelaah adanya perkembangan game online tersebut didasarkan pada beberapa keunggulan yang dihadirkan dibandingkan dengan game offline. Dengan game online, pemain dapat bermain dengan jumlah pemain yang tidak terbatas dan juga adanya kesempatan untuk dapat bertemu dengan pemain game (gamers) lainnya. Selain itu perkembangan game online saat itu juga telah menghadirkan adanya industri game centre yang menyediakan jasa bagi para gamers untuk menghabiskan waktunya guna bermain game. Kehadiran game online setidaknya telah menyebabkan adanya dampak baik positif maupun negatif yang saling bertolak belakang. Dampak negatif misalnya saja adanya kecanduan dari para penikmat game terutama kaum remaja. Tidak jarang kita jumpai saat jam-jam sekolah, para remaja yang seharusnya menghabiskan waktu mereka untuk menuntut ilmu di sekolah justru memenuhi game centre yang ada di pinggir-pinggir jalan. Selain itu yang lebih mencengangkan adalah adanya kasus-kasus kriminal dikarenakan kecanduan game online.

Kecanduan game online hampir sama dengan kecanduan narkoba, dimana orang yang sudah kecanduan bisa menghalalkan segala cara untuk memenuhi keinginannya tersebut. Beberapa kasus yang disebabkan oleh kecanduan game online, diantaranya:

1. Bulan Juli 2012, di Surakarta ditemukan 7 kasus kriminal pencurian yang dilakukan oleh anak-anak akibar kecanduan game online. (Primartantyo, 2012)

2. Bulan Februari 2012 di Taiwan, seorang ditemukan tewas di depan komputer hanya karena kelelahan setelah bermain game selama 23 jam. (Purwanti, 2012)

Berbagai macam tindakan kriminal yang diakibatkan kecanduan game online tersebut tentu menjadi sebuah refleksi bagi kita bersama. Dimana di tengah marak dan suburnya industri game online saat ini ada harga mahal yang harus dibayarkan. Game online memang telah menjadi fenomena tersendiri, tidak hanya bagi anak-anak dan remaja namun juga para orang tua. Akan tetapi, sejumlah kasus yang ada memang menyiratkan bahwa remaja memang menjadi publik yang paling banyak mengkonsumsi game online ini. Dengan berbagai motivasi yang ada dalam mengakses game online, yakni sebagai hiburan setelah lelah beraktivitas mereka juga dapat bersosialisasi dan berinteraksi dengan para gamers lainnya di dalam suatu game centre.

Kebutuhan akan suatu hiburan yang kemudian disalurkan melalui game tersebut, sebenarnya suatu yang wajar, 
apabila mereka lakukan sesuai porsinya. Namun yang menjadi permasalahan adalahpararemajaataupunpenikmatgame lainnya belum bisa membagi waktunya dengan baik. Apalagi para remaja dengan segala keingintahuan mereka, terkadang belum bisa membedakan game yang layak untuk dikonsumsi dan tidak. Hal ini dikarenakan perkembangan game online tersebut, menjadikan adanya keberagaman dari konten-konten ataupun jenis permainan yang ada.

Unsur pornografi jelas tidak dapat dipisahkan dari game online, bahkan yang menjadi miris adalah saat ini telah banyak game yang menyajikan konten permainan dengan unsur-unsur pornografi seperti misalnya adegan mandi seorang perempuan ataupun adegan pemerkosaan. Bagi orang dewasa tentu hal tersebut dapat disikapi secara bijaksana dengan memilih gamegame yang memang cukup berkualitas tanpa adanya unsur-unsur pornografi di dalamnya. Akan tetapi, bagi para remaja tentu menjadi suatu yang harus diperhatikan bersama dimana seharusnya para penyedia jasa game online mampu membuat filter tentang game-game yang bisa diakses para gamers.

Hal-hal di atas merupakan sejumlah dampak negatif dari kehadiran game online. Akan tetapi kehadiran game online juga memberikan dampak positif yakni dengan tumbuh suburnya industri kreatif dari game itu sendiri yang tentu saja berpengaruh pada perekonomian bangsa. Saat ini bahkan sudah ada perusahaan pengembang game (game developer) luar, seperti Gameloft yang membuka cabang di Indonesia dan publisher game besar seperti SquareEnix yang sudah merilis game Final Fantasy dalam bahasa Indonesia.
Dari segi internal jumlah pengembang lokal juga mengalami peningkatan di kota-kota besar seperti Jakarta, Bandung, Surabaya, Yogyakarta dan lainnya. Bahkan adanya fenomena game juga telah menyebabkan adanya institusi pendidikan yang sudah mulai membuat spesialisasi jurusan IT di bidang Game Development dan yang cukup membanggakan adanya keluarnya game online pertama di Indonesia bergenre MMOPRG dengan nama Nusantara Online. (Sanman, 2012)

Industri game online yang merupakan salah satu sektor ekonomi kreatif saat ini memang sudah sangat berkembang pesat, bahkan sepanjang tahun 2011 saja industri kreatif telah menyumbangkan tujuh persen Produk Domestik Bruto (PDB). Pencapaian tersebut, menempatkan sektor ekonomi kreatif pada urutan ketujuh yang menyumbangkan PDB terbesar. Penyerapan tenaga kerja juga tidak main-main karena pada tahun 2010 saja jumlah tenaga kerja kreatif mencapai 8,6 juta orang dari total tenaga kerja nasional 108,2 juta (7,9 persen). (Tempo, 16 Desember 2012:118)

Dengan melihat dampak baik positif dan negatif yang ditimbulkan oleh kehadiran game online serta industri kreatif yang ada di dalamnya, tentunya menjadi perhatian kita. Adanya dampakdampak negatif, haruslah kita berpikir untuk kemudian dapat ditanggulangi atau paling tidak diminimalisir. Untuk itulah dalam paper ini akan berusaha mengkaji bagaimana tantangan industri kreatif game di Indonesia hendaknya dijalankan agar nantinya dapat tetap bertahan dan memberikan manfaat bagi kemajuan bangsa Indonesia ini. 


\section{Pembahasan}

Sebelum membicarakan lebih jauh mengenai bagaimana industri game online di Indonesia dalam kaitannya dengan tantangan yang harus dihadapi. Sedikit akan dijelaskan mengenai apa itu yang disebut dengan game ataupun permainan dimana merupakan sebuah ekspresi kreatif yang menghibur dan interaktif untuk dapat dimainkan dan memiliki tujuan, memiliki pelaku aktif serta tantangan dalam mencapai tujuan tersebut. Game termasuk dalam bidang Multimedia Interaktif (Crawford, 2003:56).

Dari hal di atas, menyiratkan bahwa di dalam suatu permainan ataupun game terdapat suatu interaksi untuk mencapai suatu tujuan serta ada tantangan besar yang harus dihadapi untuk mengalahkan lawan. Oleh karena dibutuhkan suatu strategi khusus dan kreativitas yang besar dari setiap pemain untuk dapat memenangkan suatu game.

Karakteristik dari game online ini adalah pada penggunaan teknologinya itu sendiri. Oleh karenanya game online lebih sering disebut sebagai sebuah teknologi jika dibandingkan dengan sebuah genre permainan. Dalam hal ini adalah sebuah mekanisme untuk menghubungkan pemain bersama dibandingkan dengan pola-pola terentu dalam sebuah permainan (Rolling dan Adam, 2006:770)

Ketika membicarakan tentang suatu produk dalam hal ini adalah game tidak dapat dilepaskan dari industri kreatif yang telah berperan menghasilkan produk tersebut. Sehingga ketika mengkaji mengenai game online, maka juga akan mengkaji tentang industri game itu sendiri.

Saat ini indutri game di Indonesia memang telah berkembang sedemikian rupa. Akan tetapi jika dibandingkan dengan jumlah pengguna dari game sendiri, ternyata jumlah pengembang lokal ternyata cenderung mengalami pertumbuhan yang lambat. Seharusnya jumlah pengguna yang banyak bisa dibarengi dengan jumlah pengembang sehingga nantinya akan terjadi keseimbangan antara jumlah produk dengan kebutuhan pasar. Apabila dibandingkan dengan produk game luar yang masuk ke pasar Indonesia maka jumlah pengembang game lokal pun belum mencapai satu persen. Tentu hal ini menjadi pertanyaan besar, mengapa hal tersebut dapat terjadi? Padahal jika melihat dari banyaknya sumber daya manusia yang ada di Indonesia sangat memungkinkan sekali jumlah tersebut dapat ditingkatkan bahkan dapat menyaingi pengembang (developer) gamegame luar.

Perkembangan industri game di Indonesia memang dipengaruhi oleh jumlah pengguna game online sendiri. Pada tahun 2006-2010 saja mengalami pertumbuhan sekitar $30 \%$, pada tahun 2010 saja sudah terdapat 30 juta pengguna game online di Indonesia dengan ratarata umur pengguna antara 17 hingga 40 tahun. Apabila digabung dengan jumlah jenis lainnya maka jumlah pengguna game justru lebih banyak dan hampir menyamai pengguna internet itu sendiri yang diperkirakan mencapai 45 juta orang. Akan tetapi, mengapa game-game lokal belum bisa bersaing dengan gamegame luar? Bahkan di tahun 2011 saja tercatat hanya ada sekitar 25 studio game yang terlihat aktif menjajakan produknya ke pasar. Selidik punya selidik ternyata hal tersebut terjadi karena industri game nasional belum bisa menjadi tuan rumah di negeri sendiri. Akan tetapi bukan berarti tidak ada kemauan berarti, karena 
perkembangan industri game di Indonesia saat ini telah menunjukkan ke arah sana. Berikut adalah diagram mengenai persebaran pengembang game lokal pada tahun 2012:

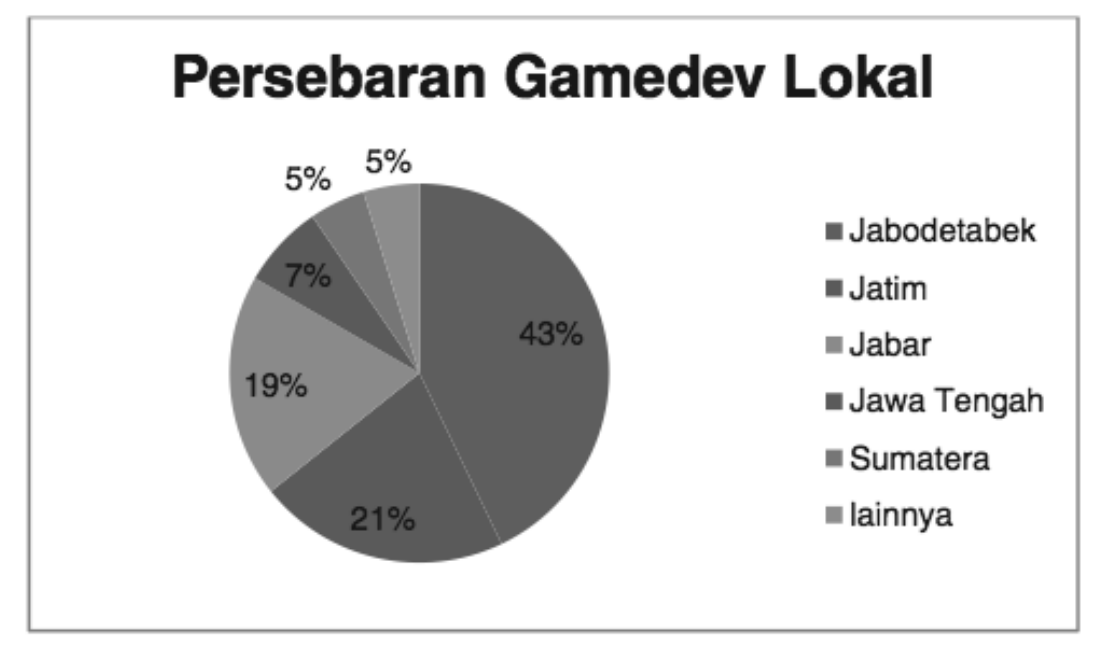

Sumber: http://www.digitalkreatif.com/industry-landscape/content-application-industry/ games-industry, diakses 6 Januari 2013

1. Dari diagram di atas, dapat dilihat bahwa selama ini persebaran pengembang game lokal masih di kota-kota besar saja. Tentu hal ini masih bisa dikembangkan lagi dengan melihat setiap peluang yang ada. Di dalam mengembangkan gamegame lokal, tidak ada salahnya juga jika pengembang lokal melakukan kerja sama dengan luar negeri baik outsourcing ataupun gamefranchise untuk menumbuhkan industri game di Indonesia yang masih hijau ini.

Jika hal itu dapat dilakukan, tentu saja pengembang game lokal dapat dikembangkan lagi yang nantinya memberikan hasil bagi peningkatan perekonomian itu sendiri. Selama ini saja, dengan berbagai keterbatasan yang ada para pengembang game lokal bisa memperoleh angka yang fantastis dari hasil game yang diproduksinya. Misalnya saja yang dialami oleh David founder Divine Kids, mengungkapkan bahwa dirinya dalam sebulan bisa mendapatkan pesanan hingga empat buah game. Baik yang berbentuk sederhana maupun yang sifatnya lebih kompleks. Dirinya bersama tim dari Divine Kids hanya membutuhkan waktu antara tiga hari hingga dua minggu saja. Padahal setiap pesanan mempunyai nilai berkisar 15 juta sampai dengan 60 juta. Lain lagi yang dialamioleh Anggoro Cahyadi pemilik Primera Bit, pengembang game lokal dari Yogyakarta. Anggoro mendulang omzet hingga 40 juta rupiah dengan mengerjakan tiga hingga empat game setiap bulan. Dirinya memberikan tarif 10 juta sampai dengan 30 juta bagi setiap game yang diproduksinya berdasarkan kerumitannya. (Fahriadi, 2011).

Dari contoh besarnya pendapatan yang diperoleh oleh para pengembang game di atas, tidak dapat dibayangkan betapa besarnya potensi industri game ini mampu memberikan penghidupan yang layak bagi pelakunya. Jika hal 
tersebut dapat dikembangkan lagi, tentu saja nilai yang dihasilkan akan jauh lebih besar.

Akan tetapi, selama ini pada kenyataannya masih banyak ditemui beberapa kendala yang menyebabkan terjadinya hambatan bagi perkembangan industri game yang ada di Indonesia. Menurut Samuel Hendry-Ketua Umum International Game Developer Association (2012:01), perkembangan industri game di Indonesia juga mengalami beberapa hambatan sebagai berikut

\section{Kurangnya perhatian dan dukungan pemerintah.}

Berbeda dengan negara-negara di Korea Selatan dan Inggris dimana para pengembang game mendapatkan dukungan pemerintah berupa pendanaan dan penyaluaran produk di Indonesia masih belum bisa seperti itu. Selama ini kebijakan pemerintah Indonesia baru sabatas memberikan fasilitas yang kemudian diharapkan menjadi dukungan para pengembang game untuk berkompetisi.

Dukungan pemerintah sangat diperlukan dalam upaya untuk mengembangkan industri kreatif game online ini. Bentuk dukungan tersebut, menurut kami dapat berbentuk adanya regulasi (aturan) yang dibuat oleh pemerintah.Jika kita lihat, selama ini regulasi yang ada justru sering kali menjadi kendala dalam pengembangan ekonomi kreatif itu sendiri. Misalnya saja dalam konteks lain, bagaimana kemudian UndangUndang No 33 Perfilman Tahun 2009, yang di dalamnya telah diatur tentang bagaimana sistem sensor film harus dijalankan dalam proses editing maka justru oleh para sineas adanya sensor yang berlebihan dianggap membatasi kreativitas dalam berkarya seni. Padahal masyarakat tentunya dapat mempunyai peranan sebagai regulator diri sendiri (self regulation), dalam hal ini adalah masyarakat mampu memilih film yang memang layak untuk dikonsumsi dan tidak.

Melihat lemahnya perlindungan pemerintah dalam melindungi hak cipta suatu industri kreatif, nampaknya memang pemerintah belum mampu membuat suatu regulasi yang benar-benar memihak pada pengembangan industri kreatif tidak terkecuali game online ini. Banyaknya pembajakan yang masih marak terjadi, tentu adalah fakta yang tidak dapat dielakkan.Betapa besar kerugian yang diterima oleh para pengembang industri kreatif Indonesia, akibat adanya pembajakan itu sendiri, tidak terkecuali dalam sektor game online.

2. Belum banyaknya institusi pendidikan yang secara spesifik memberikan pendidikan tentang bagaimana membuat serta memasarkan sebuah game.

Keterbatasan pengetahuan masyarakat akan pengembangan industri kreatif di Indonesia sendiri selama ini dikarenakan kurangnya lembaga pendidikan yang secara khusus memberikan pengetahuan untuk pengembangan industri kreatif itu sendiri. Sehingga selama ini, masyarakat mempelajari sendiri pengetahuan untuk membuat industri kreatif tersebut yang kemudian menyebabkan pengetahuan yang ada tidak mendalam.

Jika saja di Indonesia dibuat lembaga-lembaga pendidikan yang 
membekali keterampilan khusus untuk pengembangan industri kreatif tentu saja pertumbuhan ekonomi dapat lebih besar.Pembentukan lembaga-lembaga pendidikan tersebut misalnya saja dengan membuat sekolah ataupun perguruan tinggi khusus pembuatan film, game online ataupun aplikasi-aplikasi berbasis mobile phone.

Lembaga pendidikan yang secara spesifik dalam memberikan pendidikan mengenai game, semuanya masih merupakan lembaga pendidikan baru dan para lulusannya masih belum bisa menyentuh dunia industri. Hal ini kemudian menyebabkan para pengembang belajar secara mandiri (otodidak) yang berakibat kurang mendalam ilmu yang didapatkan terutama dalam dunia bisnis game.

Padahal keberhasilan suatu industri kreatif tidak terkecuali game online ini, tentu dikarenakan adanya ketercukupan pengetahuan yang dimiliki oleh para pelakunya. Mungkin saja, masyarakat Indonesia sudah cukup cerdas dalam membuat suatu produk yang kreatif namun jika mereka tidak mempunyai pengetahuan yang cukup untuk melakukan pemasaran dari produk tersebut tentu hal itu juga menjadi kendala. Olehkarenanya, pengetahuan yang cukup dari masyarakat untuk menghasilkan suatu produk yang kreatif dan juga kemampuan untuk memasarkan produk yang dihasilkan tersebut adalah penting.

3. Masyarakat Indonesia belum bisa mengapresiasi suatu karya dengan baik.

Hak atas kekayaan intelektual
(HaKI) belum bisa diimplementasikan sepenuhnya dengan masih banyaknya pembajakan dimana-mana. Berdasarkan laporan dari IDC dan BSA melaporkan tingkat pembajakan software di Indonesia mencapai 86 \% pada tahun 2011 lalu, hal ini tentu saha menyebabkan terhambatnya pertumbuhan industri digital kreatif apapun.

Menyikapi hambatan-hambatan yang ada di dalam upaya untuk mengembangkan industri game sebagaimana di atas. Setidaknya perkembangan industri game di Indonesia telah mengakibatkan adanya perubahan tren yakni yang tadinya berbasis PC ke game dengan berbasis mobile. Adanya perubahan ini didasarkan pada pertumbuhan smartphone sendiri yang terus berkembang pesat. Perubahan tersebut juga mengakibatkan para pengembang game lokal harus mengubah strategi. Pengembang game harus belajar dari game publisher dalam kaitannya dengan mempublikasi atau belajar bekerjasama dengan publisher yang berhasil. (Chandra dalam Galih, 2012)

Selain hal di atas, masih ada beberapa hambatan yang kemudian menjadi kendala dalam pengembangan industri kreatif game online ini. Kendala tersebut misalnya masalah keterbatasan dana. Hal ini tentunya merupakan faktor utama yang menjadi kendala bagi pertumbuhan dan perkembangan ekonomi kreatif. Selama ini masyarakat sudah cukup kreatif dengan menghasilkan ide-ide yang cemerlang misalnya bagaimana masyarakat mampu membuat game online sendiri, makanan ataupun kuliner yang unik, pakaian dan lain sebagainya. 
Akan tetapi apabila modal yang dimiliki terbatas, maka hal tersebut tentu tidak dapat dikembangkan dengan maksimal.

Seandainya masyarakat mempunyai dana yang cukup untuk mengembangkan industri ekonomi kreatif di sektornya masing-masing bukan mustahil dapat dikembangkan untuk sebesar besarnya kemakmuran dan kesejahteraan masyarakat. Bayangkan saja, berapa banyak tenaga kerja yang nantinya dapat diserap oleh masing-masing industri kreatif jika masing-masing sektor dapat berkembang sedemikian rupa. Tentu jumlah penggangguran dapat diminimalisir. Begitu halnya dengan jumlah kriminalitas dan kemiskinan yang selama ini banyak terjadi di Indonesia.

Oleh karenanya, peranan pemerintah sangat dibutuhkan dalam penyediaan modal dengan memfasilitasi penyediaan dana misalnya pinjaman dengan bunga ringan. Selama ini justru industri ekonomi kreatif mengantungkan penyediaan modal dari sektor swasta dalam bentuk pinjaman bank. Padahal tentunya bunga yang harus ditanggung oleh peminjam dana sangatlah besar yang kemudian nantinya mempengaruhi jalannya industri kreatif itu sendiri.

Pembangunan infrastruktur juga sangat diperlukan dalam mendukung perkembangan dari industri game online itu sendiri. Seberapa hebatnya industri kreatif yang diciptakan oleh masyarakat tanpa dibarengi dengan adanya infrastruktur tentu tidaklah dapat berjalan dengan maksimal.

Di era digitalisasi ini, pembangunan infrastruktur kerap dikaitkan dengan adanya ketersedian fasilitas internet dan masing-masing daerah, termasuk juga memeratakan akses internet tersebut. Jika saat ini masyarakat Indonesia telah dapat mengahasilkan industri game online yang kemudian mendatangkan keuntungan sampai ratusan juta rupiah setiap bulannya, namun karena keterbatasan akses internet maka masyarakat tidak dapat mengunduh game online tersebut yang nantinya berpengaruh pada jumlah permintaan game online.

Berbagai kendala yang ada di dalam pengembangan industri kreatif game online tersebut, sepatutnya diperhatikan baik bagi pelaku industri kreatif maupun dari pemerintah. Bagi pelaku industri sendiri, lebih penting rasanya apabila mereka dapat menjawab beberapa tantangan yang ada di bahwa ini dalam upaya pengembangan industri game online:

\section{Cepat dan tepat}

Perubahan perilaku konsumen dimana saat ini konsumen menginginkan segala sesuatu yang cepat dan instan menyebabkan para pengembang industri game pun harus menyesuaikan hal ini. Para pengembang diharapkan mampu melakukan pemasaran dengan cepat namun juga tepat. Dalam hal ini, diharapkan kebutuhan masyarakat akan games dapat lebih terpenuhi.

Pengguna game online umumnya menyukai game yang sudah terkenal di tengah masyarakat, mereka sangat sulit untuk perpindah ke dalam jenis permainan game baru. Oleh karena dibutuhkan suatu kecermatan bagi para pengembang game untuk membuat suatu game yang mampu menarik perhatian para pengguna game.

\section{Lain daripada yang lain (unik)}

Konsumen di Indonesia cenderung cepat merasa bosan dengan hal yang biasa saja. Tidak terkecuali pada industri 
game. Banyak sekali game baru yang bermunculan namun dengan cepat hilang. Adapun game-game seperti Warcraft Dota, Ragnarok, serta Counter Strike tetap dapat bertahan lama tidak lain karena adanya keunikan serta karakteristik yang kuat dari game tersebut. Oleh karenanya, dalam memproduksi sebuah game diperlukan adanya kreativitas lebih dari para pengembang game yang ada di Indonesia untuk dapat menciptakan suatu game dengan karakteristik kuat (unik) supaya dapat digemari oleh para konsumen game.

Sebenarnya para pengembang game lokal menurut kami sudah cukup kreatif dalam membuat suatu game yang unik namun hal itu harus senantiasa ditingkatkan agar mampu menarik perhatian. Belum lama ini telah diciptakan game untuk melawan para koruptor. Dikisahkan dalam game tersebut, para koruptor menjadi sosok antagonis yang menjadi musuh dalam permainan. Ada beberapa tokoh koruptor yang ditampilkan, yakni: Nazaruddin, Gayus Tambunan, dan Angelina Sondakh.

Di dalam game tersebut, para pemain kemudian memburu tokoh-tokoh koruptor tersebut. Ada strategi dan rintangan yang harus mereka gunakan untuk dapat menangkap para koruptor tersebut. Pemain menggunakan senjata seperti ketapel untuk melukai para koruptor. Hal yang menarik di dalam game ini adalah pada pemilihan latar belakang tempatnya, dimana sama persis dengan lokasi para koruptor ditangkap oleh KPK, tidak terkecuali di Gedung Dewan Perwakilan Rakyat itu sendiri.

\section{Menciptakan suatu game yang menghibur namun mendidik}

Sebagaimana sudah disebutkan di awal, bahwa game-game online yang ada saat ini tidak dapat dilepaskan dari unsurunsur pornografi. Oleh karena itulah para pengembang game lokal di Indonesia harus mampu memperhatikan hal ini. Dimana diharapkan para pengembang mampu membuat game yang menghibur namun tetap berlandaskan pada nilainilai yang ada atau mampu memberikan pendidikan (edukasi) bagi para penggunanya.

Dengan kata lain diharapkan suatu game mampu berperan sebagai suatu media pembelajaran bagi konsumennya. Media pembelajaran sendiri merupakan perantara sampainya pesan belajar (message learning) dari sumber pesan (message resource) kepada penerima pesan (message receive) sehingga terjadi interaksi belajar. (Munir, 2008:47)

Sejauh pengamatan kami, sebenarnya telah banyak game-game online yang memiliki fungsi demikian misalnya saja pada game Point Blank yang menuntut para pemain untuk membuat suatu taktik dan strategi dalam berperang ataupun juga pada RF Online. Meskipun kedua game tersebut adalah game tentang peperangan/pertempuran, akan tetapi pengguna game dituntut untuk dapat berfikir dengan penuh kreativitas dalam membuat suatu strategi berperang. Apabila para pengembang dapat membuat game yang berkualitas dengan menyisipkan nilai-nilai edukasi, diharapkan nantinya game yang dihasilkan oleh para pengembang game lokal mampu memberikan peningkatan kecerdasan ke arah positif.

\section{Membuat batasan segmentasi}

Tidak semua game bisa dikonsumsi oleh semua khalayak. Misalnya saja pada game-game yang memang hanya 
layak diakses oleh orang-orang dewasa. Akan tetapi karena tidak adanya sensor ataupun regulator sehingga game-game tersebut bisa diakses oleh para remaja maupun anak-anak yang masih di bawah umur. Oleh karenanya diharapkan para pengembang game lokal harus membuat suatu segmentasi berdasarkan usia yang jelas bagi game yang di produksinya.

Segmentasi ini harus dipahami betul agar para pengembang game juga tidak salah dalam menetapkan sasaran dan target di masa mendatang. Hal ini mengingat semua permainan game online saat ini telah bisa diakses secara tidak terbatas oleh semua umur tidak terkecuali yang berbau pornografi. Bahkan saat ini telah ada game lokal, yang khusus dibuat untuk menampilkan sisi erotisme dan pornografi, yakni game adegan pemerkosaan. Pemain menjadi seorang laki-laki yang kemudian menggunakan kekuatannya untuk dapat memperkosa perempuan tersebut, tentu hal tersebut sangat disayangkan dan tidaklah tepat apabila diakses oleh anak di bawah umur.

Melihat fakta di atas bahwa saat ini permainan game online telah berkembang sedemikian rupa, tentu sangatlah berbahaya jika jenis game tersebut diakses oleh anak di bawah umur. Segmentasi diperlukan dalam hal ini, selain juga peran dari para pengembang game sendiri yang kemudian dihara Bahkan tidak menciptakan game perusak moral bangsa.

\section{Berbasis komunitas}

Para gamer biasanya menyukai game-game yang hidup yakni adanya interaksi di antara para pemainnya melalui komunitas-komunitas suatu game. Oleh karenanya dengan membuat suatu game yang berdasarkan pada apa yang diharapkan atau dibutuhkan oleh komunitas yang kemudian diperlukan adanya interaksi langsung antara setiap pemain menjadi sangat penting bagi kesuksesan pengembang game lokal untuk membuat suatu game. Sebagai contoh adanya komunitas game online misalnya saja melalui website: www. ligagame.com.

Selain itu, di Bandung juga ada komunitas Game Developer Bandung (GDP), di sini semua orang dapat berbagi dan kumpul-kumpul untuk membicarakan seputar masalah game. Dengan adanya obrolan-obrolan santai, yang para penggila game ini dapat menambah semangat, motivasi serta kepercayaan diri karena melihat adanya teman yang telah berhasil mengembangkan industri game tersebut. Mereka juga dapat mendiskusikan mengenai bagaimana orang yang telah sukses menekuni industri game online, dari mulai merintisnya dan mengembangkannya. Hal ini dikarenakan kebanyakan di antara para anggota komunitas game ini ternyata adalah perusahaan super besar yang menjadi pemegang kunci dari perkembangan industri game di Indonesia.

\section{Menyesuaikan dengan kebutuhan pasar}

Membuat suatu produk tentu harus disesuaikan dengan apa yang sebenarnya dibutuhkan oleh pasar. Begitu halnya dengan industri game di Indonesia, para pengembang lokal harus mengetahui benar apa yang sedang menjadi tren pasar. Selain itu pengembang game lokal harus mengetahui kekuatan dan kelemahan dari pengembang dari luar negeri.

Pengembang game lokal hendaknya 
juga harus melihat peluang yang bisa digarap. Menurut Samuel Hendry-Ketua Umum International Game Developer Association (2012) Setidaknya ada beberapa peluang yang bisa digarap oleh pengembang game lokal:

a. Games dengan citra rasa lokal dan gameplay menarik merupakan salah satu kelebihan yang tidak dimiliki oleh pemain luar

b. Pengembang game lokal bisa memulai merintis game-game yang bersifat lebih serius, misalnya: game untuk dunia bisnis ataupun pendidikan

c. Membuat game-game yang bersifat edukasi untuk anak-anak juga belum banyak digarap oleh pengembang game lokal, padahal anak-anak merupakan salah satu pengguna game yang cukup besar.

Demikianlah menurut kami, tantangan industri game online di Indonesia yang harus dijawab bersama oleh seluruh pengembang game lokal itu sendiri. Apakah ke depannya industri game lokal dapat menjadi tuan rumah dengan digemari oleh para gamers itu sendiri ataukah game lokal tetap menjadi second choice dibandingkan game-game luar. Tentu dibutuhkan kerjasama yang saling bersinergi antara sektor swasta (pengembang game), dengan pemerintah (pemegang kekuasaan) dan masyarakat itu sendiri untuk dapat mengembangkan industri kreatif di bidang ini.

\section{Simpulan}

Berdasarkan pembahasan mengenai tantangan industri kreatif, dalam hal ini adalah game online di Indonesia sebagaimana telah dipaparkan di atas, setidaknya dapat ditarik kesimpulan, sebagai berikut:
1. Ibarat dua sisi mata uang yang bertolak belakang, adanya perkembangan industri kreatif game online selain berpengaruh terhadap peningkatan perkenomian juga ada dampak negatifnya. Dampak negatifnya, seperti adanya kecanduan bagi para pengguna game, yang kemudian dapat mengarah pada tindakan kriminal dan juga pada bahaya pornografi yang ada di dalam permainan game online tersebut.

2. Meskipun telah terbukti membantu pertumbuhan perkenomian, akan tetapi industri kreatif game online ini masih belum dikelola dengan baik serta banyak kendala yang menjadi penghambat bagi perkembangannya. Adapun beberapa kendala tersebut, diantaranya: kurangnya modal yang dimiliki oleh para pengembang, tidak adanya dukungan dari pemerintah, serta kurangnya lembaga pendidikan yang secara khusus memberikan keterampilan bagi pembuatan serta pemasaran game online ini.

3. Game lokal belum menjadi tuang rumah di negeri sendiri. Hal ini dikarenakan jumlah pengembang game lokal belum sebanding dengan jumlah pengguna game itu sendiri. Pasar game online saat ini telah berkembang sedemikian rupa seiring dengan perkembangan teknologi itu sendiri tak terkecuali smartphone. Adanya smartphone telah mendorong perkembangan game-game berbasis mobile sehingga menyebabkan pengguna game mengalami peningkatan yang luar biasa. Oleh karenanya kebutuhangame akan terus meningkat, untuk memenuhi kebutuhan tersebut tentunya harus dibarengi dengan industri game-game lokal yang mampu bersaing dengan game luar. 
4. Belum adanya institusi khusus yang mengkaji mengenai pembuatan game itu termasuk bagaimana cara pemasarannya. Sehingga selama ini para pengembang game lokal mempelajari sendiri ilmu tentang game, yang menyebabkan mereka pada akhirnya mampu menghasilkan sebuah game namun tidak dapat memasarkannya dengan baik.

5. Kurangnya dukungan dan peran serta dari pemerintah untuk turut membantu mengembangkan industri game ini. Padahal jika pemerintah memberikan dukungan dengan bentuk dana yang dikeluarkan sebagaimana di Korea Selatan, niscaya industri kreatif di bidang ini dapat berkembang lebih pesat lagi yang mana nantinya juga akan meningkatkan perekonomian bangsa Indonesia itu sendiri.

6. Dibutuhkan adanya kerjasama antara pemerintah dan serta para pelaku industri game lokal untuk dapat mengembangkan industri game ini agar dapat lebih meningkatkan pertumbuhan perekonomian itu sendiri. Para pengembang game diharapkan juga dapat menciptakan game berkualitas, yang tidak hanya bersifat hiburan semata namun juga adanya nilai-nilai edukasi bagi gamers.

\section{Daftar Pustaka}

Crawford, Chris. 2003. Chris Crawford on Game Design. USA: New Riders Publishing.

Fahriadi, 2011. Bukan Main Potensi Industri Game Lokal. (http://peluangusaha. kontan.co.id/news/bukan-mainpotensi-industri-game-lokal-1, diakses 06 Januari 2013 pukul 17.30)

Febriana. 2012. Dampak Permainan Game
Online Terhadap Siswa. (http:// eprints.uny.ac.id/8590/2/BAB\% 20 1\%20-\%2008413244048.pdf, di download 05 Januari 2013 pukul 13.15)

Galih, Bayu. 2012. Tren Berubah, Ini Tantangan Industri Game di Indonesia. (http://teknologi.news.viva.co.id/ news / read/358003-tren-berubah-ini-tantangan-ind ustri-game-diindonesia, diakses 05 Januari 2013 pukul 12.45)

Hendry, Samuel. 2012. Game Industry. (http:/ / www.digitalkreatif.com/ industry-landscape/contentapplication-industry/gamesindustry, diakses 06 Januari pukul 17.55)

Majalah Tempo. Edisi 10-16 Desember 2012.

Munir. 2008. Kurikulum Berbasis Teknologi Informasi dan Komunikasi. Bandung: Alfabeta.

Primartantyo, Ukki. 2012. Kecanduan Game Online Anak Bisa Kriminal. (

http:/ / ww w.tempo.co/read / news / 2012/07/01/108414065/ Kecanduan-Game-Online-AnakBisa-Kriminal, diakses 05 Januari 2013 pukul 12.45)

Purwanti, 2012. Lagi, Gamer Ditemukan Meninggal di Depan Meja Komputer. (http:/ / tekno.kompas.com / $\mathrm{read} / 2012 / 02 / 07 / 08305248 /$ Lagi. Gamer.Ditemukan.Meninggal. di.Depan.Komputer, diakses 06 Januari 2013 pukul 13.05)

Sanman, 2012. Perkembangan Industri Game Online. (http://universal. hermantan.com / 2012 / 01 / perkembangan-industri-game-diindonesia.html, diakses 07 Januari 2013 pukul 06.10)

Rollings, Andrew; Ernest Adams. 2006. Fundamentals of Game Design. London: Prentice Hall. 